\title{
KARAKTERISTIK REPRODUKSI INDUK IKAN BAUNG (Mystus nemurus) GENERASI PERTAMA STOK JATILUHUR
}

\author{
Ningrum Suhenda"), Atmadja Hardjamulia"), dan Ongko Praseno")
}

\begin{abstract}
ABSTRAK
Penelitian ini merupakan kelanjutan dari penelitian terdahulu yang menunjukkan bahwa ikan baung stok Jatiluhur mempunyai kualitas relatif lebih baik daripada stok Cirata, Wadaslintang, dan Wonogiri dalam hal pertumbuhan maupun kemampuan reproduksinya. Penelitian ini bertujuan untuk mendapatkan induk generasi pertama dan mengevaluasi karakteristik reproduksinya serta pertumbuhan dan sintasan benih yang dihasilkan. Penelitian dilakukan dalam keramba jaring apung di Cirata, dengan pakan yang diberikan berupa pelet tenggelam (kadar protein sekitar $30 \%$ dan lemak sekitar $6 \%$ ). Pemijahan dilakukan dengan cara pembuahan buatan. Hasil penelitian menunjukkan bahwa telah diperoleh 118 ekor induk dengan variasi bobot antara $340-910 \mathrm{~g}$, terdiri atas 63 ekor induk betina dan 55 ekor induk jantan. Pertumbuhan pada fase induk ternyata relatif lambat. Induk yang matang gonad pada bulan Januari 2002 mencapai $67 \%$. Pertumbuhan benih yang dihasilkan sampai umur 40 hari menunjukkan kecenderungan linier dengan persamaan, $Y=1,8885 X+0,9865$; dengan $R^{2}=0,9966$ dan sintasannya $70 \%$. Informasi karakteristik reproduksi lainnya adalah indeks ovisomatik $(5,3 \%-14,7 \%)$, jumlah telur ovulasi antara $44.100-66.130$ butir per $\mathrm{kg}$ induk dan periode laten antara $12-17$ jam.
\end{abstract}

ABSTRACT: Reproduction characteristic of first generation of green catfish (Mystus nemurus) Jatiluhur stock. By: Ningrum Suhenda, Atmadja Hardjamulia, and Ongko Praseno

The objectives of the study were to evaluate reproduction characteristic of green catfish (Mystus nemurus) broodstock (first generation of Jatiluhur stock), growth and survival rates of the offspring. The experiment was conducted in floating net cages at Cirata Reservoir. The sinking feed contains $30 \%$ protein and $6 \%$ fat was used as broodstock was feed with daily ration $2 \%$ of body weight. The results showed that there were 118 broodstock (63 females and 55 male) with body weight in between $340-910 \mathrm{~g}$. The growth of broodstock relatively slow. The percentage of broodstock with mature gonad reached $67 \%$ of the total number of fish on January 2002. The index ovisomatic was in between $5.3 \%-14.7 \%$, the number of eggs $44,100-66,310$ per $\mathrm{kg}$ broodstock and the latent period was in between 12-17 hours. There was linierly growth with equation $Y=1.885 \pm$ 0.9865 with coefficient correlation $R^{2}=0.9966$ and survival rate $70 \%$ for offspring of 40 days old.

KEYWORDS: $\quad$ reproduction characteristic, green catfish, Jatiluhur stock, first generation

\section{PENDAHULUAN}

Ikan baung (Mystus nemurus) merupakan ikan perairan umum yang mempunyai prospek untuk dibudidayakan. Jenis ikan ini mudah dipelihara di kolam atau dalam keramba jaring apung (KJA), dan dapat cepat menyesuaikan diri terhadap pemberian pakan buatan (Hardjamulia \& Suhenda, 2000). Jenis ikan ini sudah dikenal masyarakat karena penyebarannya yang relatif luas di Pulau Jawa, Sumatera, dan Kalimantan (Roberts, 1989). Ikan ini digemari masyarakat khususnya di Sumatera, seperti di Jambi (Nasution et al., 1993) dan di Riau (Sukendi, 2001). Di Jawa Barat, jenis ikan ini digemari masyarakat dan mempunyai harga yang relatif lebih tinggi daripada ikan mas.

Penelitian ikan baung telah banyak dilakukan mulai dari sumber dayanya di alam (Alawi et al., 1992; Utomo et al., 1993; Samuel et al., 1995; Sukendi, 2001), pembenihannya (Gaffar \& Muflikhah, 1992; Muflikhah et al., 1993; Hardjamulia \& Suhenda, 2000; Sukendi, 2001) sampai pembesarannya (Muflikhah \& Gaffar, 1992; Muflikhah \& Aida, 1996). Di Thailand, penelitian larva sejenis baung telah dilakukan pula (Amornsakun, 1999; 2000).

Hasil penelitian yang dilaksanakan pada tahun 1999 menunjukkan bahwa ikan baung yang dipelihara 
dalam KJA dapat matang kelamin dengan pemberian pakan buatan berupa pelet dengan kadar protein sekitar $30 \%$. Selain itu, ikan baung menghasilkan telur dengan diameter yang relatif besar sehingga pertumbuhan larvanya relatif cepat dan dapat lebih cepat mengkonsumsi cacing tubifex (Hardjamulia \& Suhenda, 2000).

Penyebaran ikan baung yang luas di Indonesia memberikan kemungkinan adanya plasma nutfah yang berbeda dengan karakteristik dan sifat biologi yang berbeda pula. Diharapkan di antaranya terdapat sifat pertumbuhan yang lebih baik atau sifat reproduksi yang lebih produktif. Pada penelitian sifat reproduksi keempat stok yang berasal dari Cirata, Jatiluhur, Wadaslintang, dan Wonogiri telah memberikan informasi bahwa kematangan gonad dan pemijahan dapat dilakukan sepanjang tahun. Dari aspek indeks ovisomatik (IOS) dan fekunditas, stok Cirata dan Wonogiri lebih besar daripada kedua stok lainnya. Dari pengamatan generasi pertama empat stok tersebut menunjukkan pertumbuhan, retensi protein dan lemak pada stok Jatiluhur lebih baik daripada ketiga stok lainnya.

Untuk penelitian tahun 2001 dilakukan pengamatan mengenai pertumbuhan dan karakteristik reproduksi khususnya kematangan gonad dari generasi pertama stok Jatiluhur. Tujuan penelitian ini adalah untuk mengidentifikasi karakteristik reproduksi dan pertumbuhan induk ikan baung generasi pertama stok Jatiluhur sebagai populasi yang produktif, dan untuk memperoleh data pertumbuhan dan sintasan benih yang dihasilkannya.

\section{BAHAN DAN METODE}

Induk ikan baung betina 63 ekor (bobot rata-rata $401,2 \mathrm{~g}$ ) dan jantan 55 ekor (bobot rata-rata $467,3 \mathrm{~g}$ ) yang digunakan dalam penelitian ini merupakan hasil perkawinan dari induk stok Jatiluhur hasil tangkapan dari alam, yang dilakukan secara pembuahan buatan. Telur dari satu ekor induk betina dibuahi secara buatan dengan sperma tiga ekor induk jantan. Induk ikan dipelihara di dalam keramba jaring apung (KJA) ukuran $2 \times 2 \times 2,5 \mathrm{~m}^{3}$ dengan kepadatan 40 ekor/KJA.

Selama pemeliharaan, induk ikan diberi pakan buatan berupa pelet tenggelam dengan komposisi nutriea tercantum pada Tabel 1 dengan ransum harian $2 \%$ bobot badan, dan frekuensi pemberian tiga kali per hari, yaitu pada pukul $09.00,13.00$, dan 17.00 . Pakan ditebar di atas petakan yang dibuat dari kain waring halus (mesh size $1 \mathrm{~mm}$ ) ukuran $1 \times 1 \mathrm{~m}^{2}$ yang dipasang pada kedalaman satu meter, sehingga pakan tidak lolos ke luar jaring.

Pengukuran pertumbuhan bobot calon induk jantan dan betina dilakukan dengan penimbangan masingmasing ikan dan masing-masing jenis kelamin untuk keseluruhan ikan yang ada pada setiap KJA. Pengamatan dilakukan sebulan sekali.

Laju pertumbuhan bobot harian dihitung dengan rumus:

$$
\alpha=\sqrt[t]{\left(\frac{W t}{W_{0}}-1\right)} \times 100
$$

di mana:

$$
\begin{aligned}
& W t=\text { bobot akhir }(g) \\
& W_{0}=\text { bobot awal }(g) \\
& t \quad=\text { lama waktu pengamatan (hari) } \\
& \alpha \quad=\text { laju pertumbuhan bobot harian (\%) }
\end{aligned}
$$

Pertumbuhan benih ikan baung diperoleh dengan cara mengukur panjang total tubuh dan kemudian dihitung berdasarkan rumus:

$$
a=\sqrt[t]{\left(\frac{L t}{L O}-1\right)} \times 100
$$

di mana:

Lt =panjang total akhir ( $\mathrm{mm}$ )

Lo =panjang total awal (mm)

Tabel 1. Kualitas pakan yang diberikan kepada induk ikan baung

Table 1. The quality of broodstock feed

\begin{tabular}{lr}
\hline \multicolumn{1}{c}{$\begin{array}{c}\text { Nutriea } \\
\text { Nutrient }\end{array}$} & $\begin{array}{c}\text { Berdasarkan bobot kering (\%) } \\
\text { Dry weight basis (\%) }\end{array}$ \\
\hline Protein (Crude protein) & 29.97 \\
Lemak (Fat) & 6.34 \\
Abu (Ash) & 10.55 \\
Serat kasar (Crude fibre) & 2.67 \\
Bahan ekstrak tanpa nitrogen & 50.47 \\
Nitrogen free extract & \\
\hline \multicolumn{1}{c}{ Jumlah (Total) } & $\mathbf{1 0 0 . 0 0}$ \\
\hline
\end{tabular}


$\mathrm{t}=$ lama waktu pengamatan (hari)

$\alpha=$ laju pertumbuhan panjang harian (\%)

Grafik pertumbuhan dibuat dari data panjang benih yang diukur setiap 5 hari, kemudian dibuat persamaan garis yang sesuai berdasarkan nilai $R^{2}$ yang terbesar.

Pengamatan kematangan gonad dilakukan terhadap semua ikan yang ada pada setiap KJA. Kematangan gonad dilihat pada perut yang membengkak terutama di daerah urogenital serta perkembangan oosit. Contoh oosit diambil dengan penyedotan menggunakan kateter berdiameter $2 \mathrm{~mm}$, melalui lubang genital sedalam $5 \mathrm{~cm}$. Perkembangan oosit dilihat dari ukurannya. Pengukuran oosit dilakukan secara mikroskopis dengan menggunakan micrometer. Pada ikan jantan, kematangan dilihat dari ujung papila berwarna kemerah-merahan serta keluarnya cairan pada waktu dilakukan pengurutan (stripping).

Pemijahan semua induk ikan yang matang gonad dilakukan dengan cara pembuahan buatan. Untuk merangsang ovulasi, induk ikan betina disuntik menggunakan ovaprim dengan dosis $0,9 \mathrm{~mL} / \mathrm{kg}$ induk. Penyuntikan dilakukan dua kali dengan interval waktu 6 jam, yang pertama 0,3 mL dan yang kedua 0,6 mL per kg induk. Induk jantan disuntik satu kali dengan dosis $0,5 \mathrm{~mL} / \mathrm{kg}$ induk.

Parameter yang diamati pada induk ikan yang berhasil ovulasi yaitu:

* Periode laten, yaitu kurun waktu antara penyuntikan pertama dan waktu ovulasi

* Jumlah telur yang diovulasikan dihitung berdasarkan gravimetri, yaitu perbedaan antara bobot induk sebelum dan sesudah ovulasi dikalikan dengan jumlah telur per gram

* Indeks ovisomatic (IOS) dihitung berdasarkan persentase bobot telur yang diovulasikan terhadap bobot induk sebelum dipijahkan

Pengamatan suhu air (maksimum dan minimum) dilakukan setiap hari pada pukul 09.00 pagi dengan menggunakan termometer maksimum dan minimum. Faktor kimia air yang diukur antara lain $\mathrm{pH}$, kadar $\mathrm{O}_{2}$ terlarut, $\mathrm{CO}_{2}$, alkalinitas, $\mathrm{N}-\mathrm{NH}_{4}$, dan $\mathrm{N}-\mathrm{NO}_{2}$.

\section{HASIL DAN BAHASAN}

Bobot rata-rata pada akhir penelitian calon induk ikan baung (generasi pertama) stok Jatiluhur untuk ikan betina 532,4 g sedangkan induk jantan 615,6 g. Pertumbuhan pada fase induk ini relatif rendah yang dapat dilihat dari nilai laju pertumbuhan bobot harian $(0,11 \%-0,12 \%)$. Hasil penelitian terdahulu pada ikan berukuran sekitar 328 sampai $435 \mathrm{~g}$ menunjukkan bahwa pertumbuhan jantan dan betina berbeda dengan rata-rata sebesar 15,50\% (Suhenda et al., 2002). Laju pertumbuhan bobot harian stok Jatiluhur untuk ukuran bobot antara $328-435 \mathrm{~g}$ selama periode pemeliharaan empat bulan adalah 0,22\% (Suhenda et al., 2002), sedangkan dari 25 sampai $230 \mathrm{~g}$ besarnya 1,29\% (Hardjamulia \& Suhenda, 2000). Pakan yang diberikan dengan jumlah $2 \%$ bobot badan per hari, hanya dipergunakan untuk memelihara tubuh dan perkembangan gonad. Secara fisik tubuh ikan sehat dan dari hasil pengamatan menunjukkan bahwa ovari telah berkembang dengan baik.

Perkembangan gonad sampai matang terjadi setiap bulan dengan persentase antara 42 sampai $67 \%$ dari jumlah seluruh populasi induk $(n=63)$. Nilai ini lebih tinggi dari kematangan gonad induk aslinya pada awal domestikasi, yaitu hanya sebesar $12,5 \%$ $41,6 \%(n=65)$ pada bulan Februari 2000 (Hardjamulia \& Suhenda, 2000). Pengamatan pada bulan Februari 2001 mengenai ikan baung stok Jatiluhur ini diperoleh induk yang matang gonad sampai 95\% (Suhenda et al., 2002). Hasil pengamatan menunjukkan bahwa jumlah induk matang gonad, terbanyak diperoleh pada bulan Desember dan Januari.

Sintasan ikan baung stok Jatiluhur selama pengamatan sembilan bulan untuk jenis kelamin betina dan jantan masing-masing $73 \%$ dan $88 \%$. Kematian terjadi setelah dilakukan pemijahan dengan cara pengurutan. Di samping itu, kematian juga ada yang disebabkan oleh up-welling yang terjadi pada tanggal 8 Desember 2001.

Selanjutnya pada pembuahan buatan sperma dari induk jantan dikeluarkan dengan cara pengurutan sedangkan di Balai Budidaya Air Tawar, Sukabumi pembuahan buatan dilaksanakan dengan mempergunakan sperma dari ikan yang telah dimatikan dan diambil testesnya untuk kemudian diperas sehingga sperma keluar. Mungkin cara ini lebih baik, namun induk jantan harus dimatikan. Pada umumnya derajat penetasan sangat bervariasi berkisar antara 0\%-85\% (Tabel 2). Larva setelah lepas kuning telur dapat langsung diberi pakan cacing tubifex. Kematian banyak terjadi mulai umur 15 hari yang disebabkan oleh bibit penyakit berupa Aeromonas hydrophila, Enterobacter sp., dan Micrococcus sp., namun menurut Taufik (2001), jenis yang berbahaya adalah $A$. hydrophila.

Kurva pertumbuhan benih selama 40 hari mempunyai kecenderungan garis lurus dengan persamaan $Y=1,8885 X+0,9865$ dengan $R^{2}=0,9966$ (Gambar 1). Pertumbuhan ikan merupakan kurva sigmoid, dan sampai umur 40 hari masih lurus. Hal ini menunjukkan sampai umur 40 hari pertumbuhan relatif cepat dengan laju pertumbuhan harian $7,6 \%$ (Tabel 3), sedangkan pada umur 75 hari pertumbuhan 


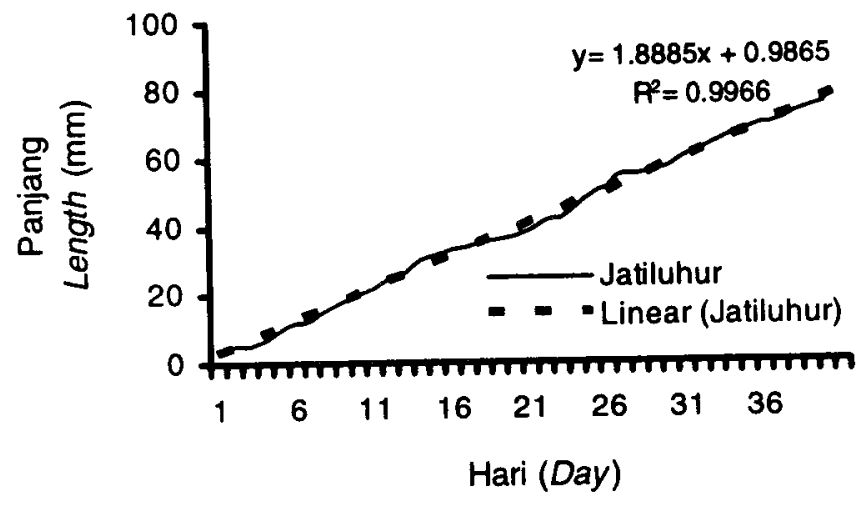

Gambar 1. Pertumbuhan ikan baung (Mystus nemurus) sampai umur 40 hari Figure 1. The growth of green cattish (Mystus nemurus) until 40 days old

Tabel 2. Karakteristik reproduksi ikan baung generasi pertama

Table 2. Reproduction characteristic of first generation green catfish

\begin{tabular}{|c|c|c|}
\hline Faktor (Factor) & Hasil (Result) & Keterangan (Note) \\
\hline Jumlah induk betina dipijahkan (ekor) & 22 & \\
\hline Broodstocks were bred & & \\
\hline Kisaran bobot induk (g) & $450-620$ & \\
\hline Broodstock weight range $(g)$ & & \\
\hline Laju pertumbuhan harian (\%) & $0.11-0.12$ & \\
\hline Daily growth rate (\%) & & \\
\hline $\begin{array}{l}\text { Frekuensi Pemijahan* (selama } 9 \text { bulan) } \\
\text { Breeding frequency (in } 9 \text { months) }\end{array}$ & 5 & $\begin{array}{l}\text { * Bulan Juni, Agust., Sept, Okt. 2001, dan Januari } \\
\text { June, August, Sept, Oct. 2001, and January }\end{array}$ \\
\hline Keberhasilan pemijahan $(\%)$ & 100 & \\
\hline Breeding success & & \\
\hline Periode laten (jam) ${ }^{* \star}$ & $12--17$ & ** 17 jam hanya satu kasus \\
\hline Latent period (hour) & & 17 hours, only one case \\
\hline Jumlah telur owlasi (butir/kg induk) & $44.100-66.130$ & *** Relatif > dari induk asli \\
\hline Number of onulated eggs (eggs $/ \mathrm{kg}$ ) & & Relative > original broodstock \\
\hline Indeks ovisomatik (\%) & $5.3-14.7$ & \\
\hline Ovisomatic index (\%) & & \\
\hline Diameter telur (mm) & $1.4-1.5$ & \\
\hline Eggs diameter $(\mathrm{mm})$ & & \\
\hline Derajat penetasan $(\%)$ & $0-85$ & \\
\hline Hatching rate (\%) & & \\
\hline
\end{tabular}

Keterangan:Nilai-nilai di atas diperoleh dari 22 kasus pemijahan Note: Values in results are from 22 breeding cases

relatif lebih lambat dengan laju pertumbuhan harian $4,29 \%$.

Hasil pengamatan suhu air permukaan dengan nilai maksimum (siang hari) dan minimum (malam hari) setiap hari di tempat penelitian di Waduk Cirata menunjukkan perbedaan antara $2,0^{\circ} \mathrm{C}-4,5^{\circ} \mathrm{C}$ per bulannya, masing-masing pada bulan Mei dan Desember 2001. Suhu maksimum $\left(31^{\circ} \mathrm{C}\right)$ terjadi pada bulan Desember, sedangkan suhu minimum $\left(26,5^{\circ} \mathrm{C}\right)$ terjadi pada bulan Mei. Kadar oksigen terlarut adalah antara 3-5 mg/L, pH 7,5; $\mathrm{CO}_{2}$ antara 9,60-13,80 $\mathrm{mg} / \mathrm{L}$ dan alkalinitas $71,20 \mathrm{mg} / \mathrm{L} ; \mathrm{N}-\mathrm{NH}_{4}$ maksimum $0,12 \mathrm{mg} / \mathrm{L}$ dan $\mathrm{N}-\mathrm{NO}_{2}$ maksimum $0,37 \mathrm{mg} / \mathrm{L}$.

\section{KESIMPULAN}

1. Dari penelitian ini telah diperoleh induk generasi pertama sebanyak 55 ekor jantan dan 63 ekor betina dengan $67 \%$ di antaranya matang gonad. 
Tabel 3. Pertumbuhan dan sintasan benih baung hasil pemijahan induk generasi pertama stok Jatiluhur Table 3. Growth and survival rate for offspring of first generation green catfish broodstock

\begin{tabular}{lc}
\hline \multicolumn{1}{c}{ Faktor (Factor) } & Hasil (Result) \\
\hline $\begin{array}{l}\text { Ukuran lana menetas }(\mathrm{mm}) \\
\text { Larva size at day one }(\mathrm{mm})\end{array}$ & 4 \\
Ukuran benih 40 hari $(\mathrm{mm})$ & $75 \pm 8.2$ \\
Seed size at 40 days old $(\mathrm{mm})$ & 7.6 \\
Laju pertumbuhan panjang harian benih ikan 40 hari $(\%)$ & \\
Daily growth rate of length $(\%)$ for 40 day old fish & \\
Ukuran benih 75 hari $(\mathrm{mm})$ & \\
Seed size 75 days old $(\mathrm{mm})$ & \\
Laju pertumbuhan panjang harian benih umur 75 hari $(\%)$ & 4.29 \\
Daily growth rate of length for 75 day old fish & \\
Sintasan benih umur 40 hari $(\%)$ & 70 \\
Survival rate for seeds 40 days old (\%) & \\
\hline
\end{tabular}

Pertumbuhan induk relatif lambat, tetapi sintasannya cukup baik dan telah dapat menghasilkan benih keturunan berikutnya.

2. Karakteristik reproduksi yang diperoleh antara lain indeks ovisomatik antara 5,3\%-14,7\%; jumlah telur ovulasi antara $44.100-66.130$ butir per $\mathrm{kg}$ induk dan periode laten antara 12-17 jam.

3. Pertumbuhan benih yang dihasilkan (sampai umur 40 hari) adalah linier dengan persamaan $Y=1,8885$ $X+0,9865$ dengan sintasan $70 \%$.

\section{DAFTAR PUSTAKA}

Alawi, H., M. Ahmad, Rusliadi, dan Pardinan. 1992. Some biological aspects of macrones catfish (Macrones nemurus C.V.) from Kampar River. Terubuk XVII, 52: 32-47.

Amornsakun, T. 1999. Some aspects in early life stages of larval red-tail catfish, Mystus wyckioides. Songklanakarin J. Sci. Technol., 21(4): 401-406.

Amornsakun, T. 2000. Influences of initial delay of feeding on growth and survival of red-tail catfish, Mystus wyckioides. Songklanakarin J. Sci. Technol., 22(1): $51-55$.

Gaffar, A.K. dan N. Muflikhah. 1992. Pemijahan buatan dan pemeliharaan larva ikan baung. Pros. Seminar Hasil Penelitian Perikanan Air Tawar 1991/1992. Balitkanwar, Bogor, p. 254-257.

Hardjamulia, A. dan N. Suhenda. 2000. Evaluasi sifat reproduksi dan sifat gelondongan generasi pertama empat populasi ikan baung (Mystus nemurus) di keramba jaring apung. J. Pen. Per. Indonesia VI(34): $24-35$.

Muflikhah, N. dan A.K. Gaffar. 1992. Pengaruh perbedaan padat tebar terhadap pertumbuhan ikan baung
(Mystus nemurus) di kolam stagnan. Bull. Pen. Per. Darat 11(2): 129-133.

Muflikhah, N., Yosmaniar, dan M. Jahri. 1993. Penelitian tehnik kawin rangsang dan budidaya ikan baung (Mystus nemurus C.V.). Rakernis Balitkanwar Sukamandi 24--26 Mei 1993, 10 pp.

Muflikhah, N. dan S.N. Aida. 1996. Pengaruh frekwensi pemberian pakan yang berbeda terhadap pertumbuhan dan kelangsungan hidup benih ikan baung (Mystus nemurus). Prosiding Lolitkanwar No. 2/1996, p. $108-111$.

Nasution, Z., A. D. Utomo, D. Prasetyo, dan S. Yusuf. 1993. Kajian ekonomi pada sumberdaya perikanan baung di DAS Batanghari, Propinsi Jambi. Rakernis Balitkanwar Sukamandi 24-26 Mei 1993, 11 pp.

Roberts, T.R. 1989. The Freshwater Fishes of Western Borneo (Kalimantan Barat, Indonesia). California Academy of Science, $210 \mathrm{pp}$.

Samuel, S. Adjie, dan Akrimi. 1995. Beberapa aspek biologi ikan baung (Mystus nemurus) di Daerah Aliran Sungai Batanghari, Propinsi Jambi. Oseanologi dan Limnologi di Indonesia, 28: 1-13.

Suhenda, N., Rusmaedi, dan A. Hardjamulia. 2002. Pertumbuhan dan perkembangan gonad empat stok ikan baung (Mystus nemurus) generasi pertama. J. Pen. Per. Indonesia VIII(5): 19-24.

Sukendi. 2001. Biologi Reproduksi dan Pengendaliannya dalam Upaya Pembenihan Ikan Baung (Mystus nemurus) di Perairan Sungai Kampar Riau. Disertasi. Program Pascasarjana IPB.

Taufik, P. 2001. Ketahanan ikan baung (Mystus nemurus) terhadap patogen Aeromonas hydrophila. Sains Akuatik IV(2): 6-12.

Utomo, A.D., Z. Nasution, dan A. Sudradjat. 1993. Aspek penangkapan dan ekologi perikanan baung di DAS Musi Sumatera Selatan. Rakernis Balitkanwar Sukamandi 24-26 Mei 1993, 14 pp. 
